\title{
Design and Implementation of Online Problem Based Learning (PBL) Assisted by Innovative Media to Improve Elementary School Student Learning Outcomes
}

\author{
Desak Made Agung Ratih Rosmilasari \\ Sekolah Dasar Laboratorium, Universitas Pendidikan Ganesha, Singaraja-Bali \\ e-mail:desakagungratih@email.com \\ Dean Putra Adoe \\ Sekolah Dasar Laboratorium, Universitas Pendidikan Ganehsa, Singaraja-Bali \\ e-mail: deanputra.id@gmail.com
}

\begin{abstract}
A R T I C L E I N F O
Article history:

1 Agustus 2020 Received in revised form

20 September 2020

Accepted 10 November 2020

Available online 20

November 2020

Kata Kunci:
PBL, online learning,
media pembelajaran
Keywords:
PBL, online learning,
learning media.
\end{abstract}

\begin{abstract}
A B S T R A K
Selama masa pandemi Covid-19 pelaksanaan pembelajaran secara online di sekolah dasar mengalami kendala dalam menyampaikan materi ke peserta didik. Penggunaan metode pembelajaran secara Full online menyebabkan kesulitan belajar sehingga berdampak pada penurunan hasil belajar siswa. Untuk mengatasi masalah tersebut maka tujuan penelitian ini adalah menerapkan model Problem Based Learning berbantuan media inovatif pada siswa kelas II untuk meningkatkan hasil belajar pada pembelajaran tematik. Penelitian ini merupakan penelitian tindakan kelas (PTK) yang dirancang dalam dua siklus. Setiap siklus memiliki 4 tahapan yaitu, perencanaan, tindakan, observasi/evaluasi, dan refleksi. Satu siklus dilaksanakan selama 3 kali pertemuan yaitu 2 kali pertemuan untuk pelaksanaan pembelajaran dan 1 kali pertemuan untuk pelaksanaan tes hasil belajar. Selama penelitian data hasil belajar diukur menggunakan tes pilihan ganda dan proses pembelajaran diukur menggunakan metode observasi. Data berupa skor dianalisis menggunakan statistik deskriptif dan data pengamatan dianalisis secara kualitatif. Hasil penelitian menunjukkan bahwa skor rerata klasikal pada siklus I adalah $81,91 \%$ (kategori tinggi) dan terjadi peningkatan pada siklus II dengan skor rerata klasikal sebesar $91,13 \%$ (kategori sangat tinggi). Dengan demikian dapat
\end{abstract} disimpulkan bahwa model PBL online berbantuan media inovatif mampu meningkatkan hasil belajar siswa.

\begin{abstract}
A B S T RA C T
During the Covid-19 pandemic, online learning implementation in elementary schools experienced problems in delivering material to students. The use of fully online learning methods causes learning difficulties, so that it has an impact on decreasing student learning outcomes. To overcome this problem, the purpose of this study is to apply the Problem Based Learning model assisted by innovative media in class II students to improve learning outcomes in thematic learning. This research is a classroom action research that is designed in two cycles. Each cycle has four stages, namely, planning, action, observation/evaluation, and reflection. One cycle is carried out for three meetings, namely two meetings to implement learning and one meeting to implement learning outcomes tests. During the research, the learning outcome data were measured using multiple-choice tests, and the learning process was measured using the observation method. Data in the form of scores were analyzed using descriptive statistics, and observational data were analyzed qualitatively. The results showed that the classical mean score in cycle I was $81.91 \%$ (high category), and there was an increase in cycle II with a classical mean score of $91.13 \%$ (very high category). Thus, the online PBL model assisted by innovative media can improve student learning outcomes.
\end{abstract}

\section{Introduction}

Thematic is a learning approach that combines several subject content so that it integrates. One of the objectives of implementing thematic learning in elementary school is that students can have better basic competencies because they can link subjects with students' personal experiences. This learning objective is certainly in line with Undiksha Elementary School's motto to produce intelligent, innovative and adaptive people. The advantages of thematic learning have also been proven through several research results that thematic learning can increase student scores and motivation (Chrisyarani \& Yasa, 2018; Mulyadin, 2016; N. A. Sari et al., 2018).

During the Covid-19 pandemic, the implementation of thematic learning, especially in the second grade at Undiksha Laboratory Elementary School, encountered many obstacles due to student learning models from face-to-face to online learning models. Parents also experience difficulties in assisting students because thematic models are very common among parents of students. Thematic has different characteristics from subjects, and 
parents have never received thematic learning in previous education. The results showed that the implementation of face-to-face thematic learning is still not optimal, and the learning process is on sufficient criteria (Alnashr, 2018; Ardiani et al., 2013; Indriani, 2015). The research indicates that face-to-face and online thematic learning needs to be designed as well as possible to make it easier for students to learn.

Thematic learning that is carried out online during the pandemic has several weaknesses that have an impact on student learning outcomes that are not optimal, and it makes students motivation decrease in learning motivation due to a sudden change in learning methods from face-to-face to full online models (Dewi, 2017; Djuniadi, 2012; Irawan et al., 2015). Parents must increase the time to accompany their children. Many students have difficulty adapting to online learning because, technically, they have never studied online in face-to-face learning at school. The density of thematic material becomes a teacher's dilemma during online learning, and of course, this material will be difficult to complete during this transitional period. Teachers also do not have readiness in terms of digital learning sources or media so that the material is mostly delivered verbally and textually. Learning media in schools is still minimal in digital form and mostly in simple media, visual aids, three-dimensional media, model media, and the like. Another weakness encountered during the pandemic is that students quickly get bored because it is not like face-to-face learning. Based on listening to parents' input that students need more real interaction with various learning sources in their home environment, this interaction makes students easier and more enthusiastic about learning. Some of these things indicate that online learning must be well designed to attract students' interest in learning.

Based on some of these weaknesses, the researcher designed a learning model which is expected to implement thematic learning optimally. Thematic learning outcomes are expected to be optimal by applying the Problem Based Learning (PBL) model. This model was chosen because it brings students closer to students' daily problems, especially when learning from home. The Problem Based Learning (PBL) learning model is a learning system based on students' problems during the process of gaining knowledge. Five main activity stages can be applied in PBL, starting from student orientation to the problem, then organizing students to learn, guiding investigations in groups, develop and present the work, and analyze and evaluate the results of problemsolving (Herzon et al., 2018; Romadhoni et al., 2017; Tomas \& Prasetyo, 2020). The learning syntax with the PBL strategy can be seen in Table 1 .

Table 1. Learning Syntax with Problem Based Learning Strategy

\begin{tabular}{|c|c|c|}
\hline Step & Learning Procedure & Teacher Behavior \\
\hline 1 & Oriented students on problems & $\begin{array}{l}\text { The teacher explains the learning objectives, explains the logistics } \\
\text { required, and motivates students to be actively involved in problem } \\
\text { solving activities }\end{array}$ \\
\hline 2 & Organizing students to study & $\begin{array}{l}\text { The teacher helps students define and organize learning tasks } \\
\text { related to the problem }\end{array}$ \\
\hline 3 & $\begin{array}{l}\text { Helping individual and group } \\
\text { investigations }\end{array}$ & $\begin{array}{l}\text { The teacher encourages students to collect appropriate information, } \\
\text { carry out experiments, and seek explanations and solutions }\end{array}$ \\
\hline 4 & $\begin{array}{l}\text { Produce and present works and } \\
\text { exhibits }\end{array}$ & $\begin{array}{l}\text { The teacher helps students plan and prepare appropriate work such } \\
\text { as: reports, videos, models, and helps them share their assignments } \\
\text { with others }\end{array}$ \\
\hline 5 & $\begin{array}{l}\text { Analyze and evaluate the } \\
\text { problem-solving process }\end{array}$ & $\begin{array}{l}\text { The teacher helps students to reflect and evaluate the investigation } \\
\text { and learning processes they use }\end{array}$ \\
\hline
\end{tabular}

In addition to using the PBL model, innovative learning media are also applied following the $21 \mathrm{st}$ Century era and the 4.0 industrial revolution. In the 21 st century and known as the Industrial Revolution 4.0 era, many media have changed. Today many messages are presented in multimedia format. Innovative media in research will adopt several multimedia learning design principles, namely: (1) Multimedia Principles; (2) the principle of proximity to space; (3) The Principle of Tempo Proximity (Time); (4) Principle of Coherence (Harmony); (5) Principle of Modality; (6) Principle of Redundancy; and (7) Personalization Principles (Awalia et al., 2019; Ibrahim \& Ishartiwi, 2017; Tembang et al., 2020).

PBL designed electronically is an innovation in online learning to optimize the learning process. Each cycle will be facilitated with digital or electronic learning media such as audio, video, tutorials, and animation. This learning media is designed based on multimedia theory so that thematic learning materials can be easier to understand. The use of multimedia also has a positive impact on student motivation and learning outcomes when compared without using multimedia (Pranowo \& Prihastanti, 2020; Priyambodo et al., 2012; D. S. Sari \& Sugiyarto, 2015). 
Several studies that are relevant to this research are (1) research conducted by (Maryatun \& Metro, 2017), who obtained the results of the study that the PBL learning model had a positive effect on student learning outcomes; (2) research conducted by (Setyaningsih et al., 2020), who obtained the results of the study that the use of interactive learning media based on articulate storylines had an effect on student motivation and social studies learning outcomes; (3) research conducted by (Rerung et al., 2017), who obtained research results that the application of the PBL learning model can improve student learning outcomes.

This study aimed to analyze the implementation of online problem-based learning (PBL) assisted by innovative media to improve elementary school students' thematic learning outcomes.

\section{Method}

The type of research carried out is classroom action research. The research was conducted on students of class II C SD Laboratoriun Undiksha from August to October 2020. The object that focuses on research attention is the thematic learning outcomes after applying the online PBL model assisted by innovative media. This research involved 23 students of class II C SD Lab Undiksha, consisting of 12 boys and 11 girls. This research was planned in two cycles, with each cycle consisting of four stages, namely: (1) planning, (2) action, (3) observation and evaluation, and (4) reflection. However, in this study's implementation, the number of cycles performed was determined by the results or the previous cycle's success rate. If the expected results have been obtained in a certain cycle, the research will not be continued to the next cycle. The stages in this research cycle are presented in Figure 1 below.

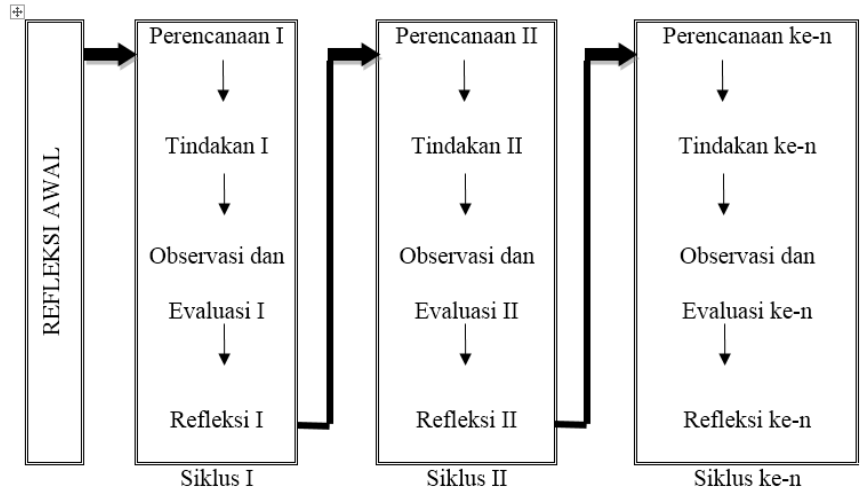

Figure 1.Stages in the Learning Cycle

Initial reflection identifies problems and initial obstacles experienced by students and teachers in the online learning process during the Covid-19 pandemic. Something needs to be done to improve the weaknesses of the methods applied in the learning process. Initial reflection was carried out before conducting the research. It is done so that after the initial reflection is carried out, the researcher can make a research design that is expected to improve the learning problems that have been identified. Based on the results of the initial reflections that have been carried out, the classroom action research in the form of design and implementation of the PBL Online model assisted by innovative media is carried out in class II C in odd semesters at SD Lab Undiksha to be an alternative to overcome problems that occurred in the online learning process during the Covid-19 Pandemic.

Cycle I was held for three meetings, namely two meetings to implement learning and one meeting to implement learning outcomes tests. The theme discussed in the first cycle is "Living in Harmony". The second cycle is carried out in 3 meetings, namely 2 meetings for implementing learning and 1 meeting to implement learning outcomes tests. The theme taught in cycle II is "Playing in my neighbourhood". This study investigates the impact of variables in the form of innovative media-based learning models. The learning model used in this study is a problem-based learning model or Problem Based Learning. This model will be complemented by the application of digital learning media in video and animation formats. One dependent variable examined in this study is thematic learning outcomes. Student learning outcomes are obtained from the post-test results. The test form used is a multiple choice test. Multiple choice tests are presented online using the kahoot application. The observation method will be equipped with an observation sheet to observe student activities during online learning. The data obtained from the test results were analyzed using descriptive statistical analysis methods to determine each cycle's mean score. The data were analyzed descriptively qualitatively to determine student activities during online learning. Student learning outcomes can be determined by comparing M (\%) or the average percentage into the PAP scale of five with the criteria shown in Table 2. 
Table 2. Guidelines for Five Scale PAP Conversions

\begin{tabular}{cc}
\hline Percentage $(\%)$ & Criteria \\
\hline $90-100$ & Very high \\
$80-89$ & High \\
$65-79$ & Moderate \\
$55-64$ & Low \\
$0-54$ & Very low \\
\hline
\end{tabular}

The research will be terminated if student learning outcomes classically reach an average of $90 \%$ or obtain Very High Criteria.

\section{Result and Discussion}

Classroom action research (PTK) was conducted in the IIC class of the Undiksha Laboratory Elementary School for the 2020-2021 academic year with 23 students. The first cycle's research implementation was carried out in three meetings, namely two meetings for online learning and one meeting to implement tests of students' understanding abilities through the online kahoot application. The first cycle was carried out from 10 August to 28 August 2020. In the first cycle, several things were arranged, including planning the first cycle, implementing actions, observing and evaluating the first cycle, and reflecting on the first cycle. In the planning of the first cycle, there are several activities, namely: (1) preparing the first cycle of learning material with the theme of Rukun Life, (2) compiling lesson plans, (3) preparing instruments in the form of the first cycle learning outcomes tests, and (4) providing digital learning media.

The learning implementation at the first meeting of the first cycle was carried out on Monday, August 10, 2020. The learning activities at the first meeting discussed material regarding the practice of Pancasila principles in everyday life, finding the meaning of word expressions. The initial activity begins with the teacher saying greetings, giving perceptions about the learning to be carried out, and conveying the learning objectives to be achieved and the learning material to be discussed. The next activity is the core activity. In the PPKn subject matter, the teacher explains examples of implementing attitudes following the principles of Pancasila. The teacher gives a story in which there are attitudes following the principles of Pancasila. Then students are asked to classify the attitudes that appear in the story according to the principles of Pancasila. Students also asked to name each of the two attitudes examples. It has been carried out from each of the Pancasila principles in everyday life. In the content of Indonesian subjects, the teacher tells about an incident or event that occurred. Then the students were asked to find the expressions in the story that the teacher told.

Furthermore, students are asked to look for the phrase's meaning earlier with the teacher's guidance. In the final activity, the teacher conducts questions and answers to check how students understand students' material and correct if they are wrong in answering the teacher's questions. The teacher and students conclude the lesson that has been implemented and carry out reflection. Then, the teacher delivers the lesson plan at the next meeting and ends the meeting.

The learning implementation at the second meeting of the first cycle was held on Tuesday, August 18, 2020. The learning activities at the second meeting discussed material on determining place values, analyzing children's songs, and mentioning examples including locomotor and non-locomotor movements. The initial activity begins with the teacher saying greetings, giving perceptions about the learning to be carried out, and conveying the learning objectives to be achieved and the learning material to be discussed. The next activity is the core activity. In mathematics subject matter, the teacher explains the place value in numbers. The teacher gives several three-digit numbers. Then students are asked to sort out which numbers have the value of hundreds, tens, and units. Then one of the students is asked to give a three-digit number, and the teacher appoints another student to group it according to his place value. In the SBdP subject content, the teacher provides song lyrics. Then the teacher assigns students to guess the title of the song and its creator and complete the gaps in the lyrics. In PJOK content, the teacher shows pictures to students. Then the students were asked to observe the picture and guess which image was included in locomotor motion and which image was included in non-locomotor motion with the teacher's guidance. In the final activity, the teacher conducts questions and answers to check how students understand students' material and correct if they are wrong in answering the teacher's questions. The teacher and students conclude the lesson that has been implemented and carry out reflection. The learning process carried out is still the same as the first meeting. However, at the second meeting, the students had started to see changes. This change can be seen when students are asked to answer and sort out the pictures according to the teacher's instructions. The number of students who dared to express their opinions was far more than before. 
The third meeting was held on August 28, 2020. At this meeting, the teacher gave 25 multiple-choice tests to students. The questions used are related to the theme of Hidup Rukun, which students study. The teacher gives 60 minutes to work on the questions. Students are given a test of learning outcomes in the first cycle using the kahoot application. Observations in the first cycle were carried out on 23 students, and the scores obtained by students occurred in Table 3.

Table 3. The distribution of scores in the first cycle

\begin{tabular}{lccccc}
\hline & $\begin{array}{c}(\mathbf{9 0 - 1 0 0 )} \\
\text { Very high }\end{array}$ & $\begin{array}{c}\mathbf{( 8 0 - 8 9 )} \\
\text { High }\end{array}$ & $\begin{array}{c}\mathbf{( 6 5 - 7 9} \\
\text { Moderate }\end{array}$ & $\begin{array}{c}(\mathbf{5 5}-46) \\
\text { Low }\end{array}$ & $\begin{array}{c}(\mathbf{0 - 5 4 )} \\
\text { Very low }\end{array}$ \\
\hline Total students & 7 & 11 & 2 & 2 & 1 \\
Percentage & $30 \%$ & $48 \%$ & $9 \%$ & $9 \%$ & $4 \%$ \\
\hline Classical Mean & $\mathbf{8 1 , 9 1 \%}$ & & & & \\
\hline
\end{tabular}

Based on the table above, the percentage that gets a very high category is only $30 \%$, while the highest percentage is high. It indicates that the target to be in the very high category has not been achieved. Based on the observations' results, several problems can be identified that cause student learning outcomes to be at high criteria. There are still many obstacles in implementing the PBL model online, especially in implementing PBL syntax. As for the obstacles faced, namely: (1) students are not familiar with the implementation of the PBL model online so that the results are not optimal, (2) the teacher has difficulty managing the class online because student voices enter irregularly so that it can interfere with a student focus, (3) Most students still have difficulty understanding the problems given by the teacher, (4) the innovative media presented by the teacher needs to be optimized to attract students' attention. From these problems, it was decided to: (1) present simple steps for solving, (2) provide contextual problems and following the environment and daily life faced by students, (3) provide opportunities for students individually -one solving the given problem, (4) presenting various other innovative media such as concrete objects, artificial objects, three-dimensional objects, and the environment as learning media.

The second cycle is carried out from 1 September to 12 October 2020. In the second cycle, several things are arranged, including planning the second cycle, implementing actions, the results of observations of the second cycle, and the second cycle's reflection. In the second cycle planning, there were several activities, including 1) preparing the second cycle of learning material with the theme Playing in My Neighborhood, 2) preparing lesson plans, 3) preparing instruments in the form of learning outcomes tests, and 4) providing learning media in the form of videos of concrete objects, objects knockoffs, demonstration videos, and environmental media videos. The second cycle was carried out in 3 meetings, namely two meetings for implementing learning and 1 test meeting at the end of the second cycle.

The first meeting in the second cycle was held on Wednesday, September 2, 2020 using the google meet application. The initial activity begins with the teacher saying greetings, giving perceptions about the learning to be carried out, and conveying the learning objectives to be achieved and the learning material to be discussed. The next activity is the core activity. In the PPKn subject matter, the teacher explains the rules that can be done and cannot be done. The teacher gives a story in which some rules can be done and cannot be done in everyday life. Then students are asked to group the rules according to instructions from the teacher. In Indonesian subjects, the teacher presents various objects found and used in everyday life through instructional videos. Then students are asked to guess the names of the objects shown by the teacher. Then students are asked to group these objects, which include solid, liquid, and gas objects. In addition, the teacher also gives a story to students then students are asked to find the objects contained in the story and group them. At the end of the lesson the teacher concludes the learning material and assigns assignments to students.

The second meeting of the second cycle was held on Thursday, October 1, 2020 with material on solving multiplication problems in everyday life, various simple games and imaginative pictures. The initial activity begins with the teacher saying greetings, then giving an apperception related to the learning to be carried out, followed by conveying the learning objectives to be achieved and the learning material to be discussed. The teacher also conveys the steps for implementing the lesson.

In the core activity, the teacher explains the concept of multiplication in mathematics. Then proceed with steps in solving problems in learning mathematics. The teacher also uses media in the form of fruits and marbles as objects used to explain the concept of multiplication. Furthermore, the teacher gives students problems with multiplication, and the problems given are more contextual with students' lives to be more easily understood. The teacher gives 3-5 minutes for students to solve the problem. Students are given the same opportunity to submit answers to problems given by the teacher. Students convey their answers verbally and visually through their respective smartphone screens. Before the teacher provides feedback, the teacher also provides opportunities for other students to convey their answers to be comparisons. If there are already 2 
students who have submitted answers, the teacher provides feedback to the two students who have submitted their answers. The teacher praises students whose answers are correct and encourages students whose answers are not correct.

Furthermore, in the SBdP subject matter, the teacher assigns students to combine two objects in one picture, which results in an interesting imaginative picture. Furthermore, in the subject matter of PJOK, students are shown pictures of traditional games, and the teacher asks students to guess the name of the game. Then the teacher explains details about the types of games mentioned earlier. At the end of the activity, the teacher and students conclude the material that was studied. In this second cycle, the students had seen the changes very much. This change can be seen when students are asked to solve problems. Many students have dared to raise their hands to convey their answers. It shows that students can better understand the problems given and find solutions to the problems given.

The third meeting was held on October 15, 2020. At this meeting, the teacher gave a multiple-choice test to students totalling 25 questions. The questions used are related to the theme of Playing in My Environment, which students learn. Students are given a second cycle of learning outcomes test with 60 minutes to use the kahoot application. Observations in the second cycle were carried out on 23 students, and the score mapping was presented in Table 4 .

Table 4. Distribution of Scores in the Second Cycle

\begin{tabular}{lccccc}
\hline & $(\mathbf{9 0 - 1 0 0 )}$ & $\mathbf{( 8 0 - 8 9 )}$ & $(\mathbf{6 5 - 7 9}$ & $\mathbf{( 5 5 - 4 6 )}$ & $(\mathbf{0 - 5 4 )}$ \\
& Very high & High & Moderate & Low & Very low \\
\hline Total students & & 5 & 2 & & - \\
Percentage & & $22 \%$ & $9 \%$ & & - \\
\hline Classical Mean & & & \\
\hline
\end{tabular}

Based on the results described above, the implementation of the second cycle's action is more optimal than the first cycle's implementation. As much as $70 \%$ of students have scored in the very high category, 22\% high, and $9 \%$ moderate, and the mean classical score is 91.13 , which is in the very high category. It was easier for teachers to implement PBL online based on the first cycle's weaknesses in the second cycle. Likewise, learning media in the second cycle is more varied and more contextual so that abstract concepts can be understood well by students. Based on the results of reflection in the second cycle, it can be concluded that the implementation of online PBL accompanied by innovative media can improve student learning outcomes. The comparison of the improvement in learning outcomes from the first cycle to the second cycle can be seen in Figure 2.

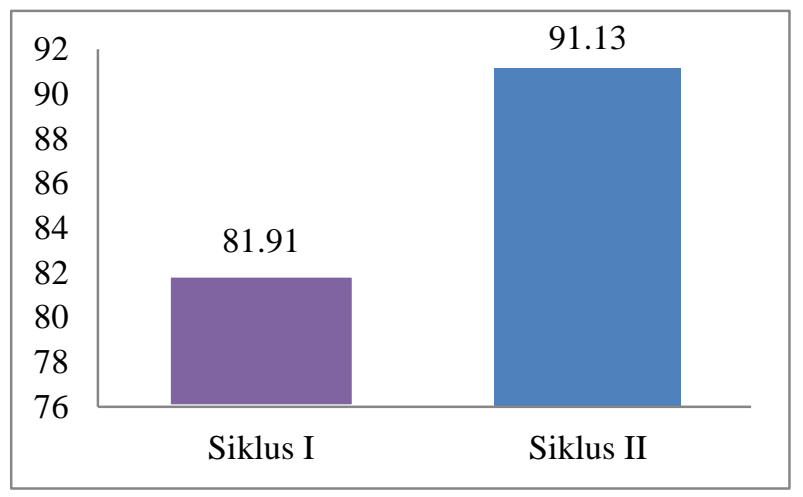

Figure 2. Improved Scores from the first cycle and the second cycle

The problem-based learning model implemented in class II C of the Undiksha Laboratory Elementary School showed increased student learning outcomes. It can be seen from the difference in the average test score. The mean of learning outcomes in the first cycle was 81.91 (high category) and the mean learning outcomes in the second cycle was 91.13 (very high category). This increase is thought to be due to the following factors.

First, giving problems that make children more motivated to learn because of challenges to solve problems. Motivation is the most important part of special learning during the Covid-19 pandemic. Thus, the teacher provides a stimulus to give students problems following the level of student development and can be 
solved by students with learning resources around students. Empirically, problem giving also affects increasing learning motivation. The problems given by the teacher are real problems that exist around the student's environment such as multiplication problems raise the topic of activities of mothers who are buying mangoes, problems observing the types of solid objects and liquid objects in the home environment, problems with how to communicate using sentence structure, problems regarding what rules can and should not be done in the home environment. The application of the PBL model online can provide instructions and guide students in solving problems. This finding is supported by other research, which found that the PBL model's use was able to help students solve problems (Juliawan et al., 2017; Maryatun \& Metro, 2017; Novianti et al., 2020). The problems given are real problems related to the environment around students.

Second, the use of media can clarify abstract material. Students find it easier to understand the material when presented using learning media. The types of media used in the research are image media, real object media, artificial objects, puppet media, diorama media. The media is presented in a video format that is presented synchronously or asynchronously. The use of video media during online learning or learning from home is enough to attract students' interest and understand the material well. The media or objects presented in the video are also easily available to students around their homes so that what the teacher demonstrates can be followed by students. For example, students can identify these characteristics by observing objects around their home environment regarding solid and liquid material. The learning media used to make it easier for students to understand the material and foster student interest, interest, and attention to the subject matter. Several studies' results support this finding that video media can increase student interest and learning outcomes (Febryanto, 2015; Wati, 2013; Yunita \& Wijayanti, 2017).

The third factor, providing immediate feedback to students 'answers, can foster students' enthusiasm for learning. The teacher provides immediate feedback on answers or assignments at each learning session. Immediate feedback is provided via the WhatsApp group so that students immediately know their score. Live feedback is also provided via interactive quizzes via the Kahoot application. (Alkhasawneh et al., 2008; Novianti et al., 2020; Wajdi, 2017) Said that the existence of feedback could help students know the progress of their learning. Feedback can reinforce what has been learned and can also correct misunderstandings. The assessment carried out by students is expected to be a description of student deficiencies and increase understanding in the next learning process. Providing feedback can also accelerate and strengthen mastery of skills. Thus, the interactivity of an assessment and providing feedback is very important for the teacher because it will strengthen students' knowledge.

Several studies that are relevant to this research are (1) research conducted by (Maryatun \& Metro, 2017), who obtained the results of the study that the PBL learning model had a positive effect on student learning outcomes; (2) research conducted by (Setyaningsih et al., 2020), The results showed that the use of interactive learning media based on articulate storylines affected students' learning motivation and social studies learning outcomes; (3) research conducted by (Rerung et al., 2017), who obtained research results that the application of the PBL learning model can improve student learning outcomes.

Based on the results and discussion, it can be stated that the problem-based learning model using innovative media can improve thematic learning outcomes, especially in class II C students of Undiksha Laboratory Elementary School for the 2020-2021 academic year. For this reason, the online PBL learning model is an online learning pattern that can be applied to make learning more interesting and challenging for students.

\section{Conclusion}

Based on the results and discussion, it can be concluded that the problem-based learning model using innovative media can improve thematic learning outcomes, especially in class II C students of Undiksha Laboratory Elementary School for the 2020-2021 academic year. For this reason, it is suggested that the student learning process will be more optimal during the Covid 19 pandemic if there are more interactions between teachers and students and teachers have the patience to guide children to solve problems online and online learning will be optimal with the support of schools by providing training early on to teachers about online learning, its implementation, and its evaluation techniques.

\section{References}

Alkhasawneh, I. M., Mrayyan, M. T., Docherty, C., Alashram, S., \& Yousef, H. Y. (2008). Problem-based learning (PBL): Assessing students' learning preferences using vark. Nurse Education Today, 28(5), 572-579. https://doi.org/10.1016/j.nedt.2007.09.012

Alnashr, M. S. (2018). Analisis Faktor Penghambat Guru Madrasah Ibtidaiyah dalam Pembelajaran Tematik (Studi Kasus di MI Al-Hikmah Kajen, Margoyoso, Pati). Al Ibtida: Jurnal Pendidikan Guru MI, 5(2), 
191-204. https://doi.org/10.24235/al.ibtida.snj.v5i2.2959

Ardiani, N. F. W., Guna, N. A., \& Novitasari, R. (2013). Pembelajaran Tematik Dan Bermakna Dalam Perspektif Revisi Taksonomi Bloom. Satya Widya, 29(2), 93-107. https://doi.org/10.24246/j.sw.2013.v29.i2.p93-107

Awalia, I., Pamungkas, A. S., \& Alamsyah, T. P. (2019). Pengembangan Media Pembelajaran Animasi Powtoon pada Mata Pelajaran Matematika di Kelas IV SD. Kreano, Jurnal Matematika Kreatif-Inovatif, 10(1), 49-56. https://doi.org/10.15294/kreano.v10i1.18534

Chrisyarani, D. D., \& Yasa, A. D. (2018). Validasi modul pembelajaran: Materi dan desain tematik berbasis PPK. Premiere Educandum, 8(2), 206-212. https://doi.org/10.25273/pe.v8i2.3207

Dewi, L. (2017). Designing Online Learning In Higher Education Institu- Tion: Case Study In Curriculum And Instruction Course At Indonesia University Of Education. Edutech, 16(2), 205-221. https://doi.org/10.17509/e.v16i2.7616

Djuniadi, D. (2012). Fitur Motivasi Pembelajaran Online Dengan Pendekatan Pre-Defined SET. Jurnal Pendidikan Vokasi, 2(1), 41-52. https://doi.org/10.21831/jpv.v2i1.1015

Febryanto, F. N. (2015). Pembelajaran Lay Up Shoot Menggunakan Media Audio Visual Basic Lay Up Shoot Untuk Meningkatkan Hasil Belajar Lay Up Shoot Pada Siswa Kelas Viiia Smp Kanisius Pati Tahun 2013/2014. E-Jurnal Physical Education, Sport, Health and Recreation, 4(1), 1509-1521. https://doi.org/10.15294/active.v4i1.4548

Herzon, H. H., Budijanto, \& Utomo, D. H. (2018). Pengaruh Problem-Based Learning (PBL) terhadap Keterampilan Berpikir Kritis. Jurnal Pendidikan: Teori, Penelitian, Dan Pengembangan, 3(1), $42-46$. http://journal.um.ac.id/index.php/jptpp/

Ibrahim, N., \& Ishartiwi, I. (2017). Pengembangan Media Pembelajaran Mobile Learning Berbasis Android Mata Pelajaran IPA Untuk Siswa SMP. Refleksi Edukatika: Jurnal Ilmiah Kependidikan, 8(1), 80-88. https://doi.org/10.24176/re.v8i1.1792

Indriani, A. (2015). Penerapan Pembelajaran Tematik Kurikulum 2013 oleh Guru SD/MI di Desa Klepek Kecamatan Sukosewu Kabupaten Bojonegoro Semester Gasal Tahun Ajaran 2014/2015. Jurnal VARIDIKA, 27(1), 43-49. https://doi.org/10.23917/varidika.v27i1.738

Irawan, Y., Susanti, N., \& Triyanto, W. A. (2015). Analisa Dan Perancangan Sistem Pembelajaran Online (ELearning) Pada Smk Mambaul Falah Kudus. Simetris: Jurnal Teknik Mesin, Elektro Dan Ilmu Komputer, 6(2), 345-352. https://doi.org/10.24176/simet.v6i2.471

Juliawan, G. A., Mahadewi, L. P. P., \& Rati, W. R. (2017). Pengaruh Model Problem Based Learning (PBL) Terhadap Kemampuan Pemecahan Masalah Matematika. Mimbar PGSD, 5(2), 1-10. https://doi.org/http://dx.doi.org/10.23887/jjpgsd.v5i2.10881

Maryatun, \& Metro, P. E. F. U. M. (2017). Pengaruh Penggunaan Model Problem Based Learning (PBL) Terhadap Hasil Belajar Ekonomi Siswa Kelas X Semester Genap Sma Pgri 1 Metro Tahun Pelajaran 2016/2017. Jurnal Pendidikan $\quad$ EKonomi, $\quad 5(1), \quad 152-159$. https://doi.org/http://dx.doi.org/10.24127/ja.v5i2.1225

Mulyadin. (2016). Implementasi Kebijakan Pembelajaran Tematik Terpadu Kurikulum 2013 Di SDN Kauman 1 Malang Dan SD Muhammadiyah 1 Malang. Jurnal Edutama, 3(2), 31-48. https://doi.org/http://dx.doi.org/10.30734/jpe.v3i2.35

Novianti, A., Bentri, A., \& Zikri, A. (2020). Pengaruh Penerapan Model Problem Based Learning (Pbl) Terhadap Aktivitas Dan Hasil Belajar Siswa Pada Pembelajaran Tematik Terpadu Di Kelas V Sekolah Dasar. Jurnal Basicedu, 4(1), 194-202. https://www.researchgate.net/Publication/342499585_Pengaruh_Penerapan_Model_Problem_Based_Le arning_Pbl_Terhadap_Aktivitas_Dan_Hasil_Belajar_Siswa_Pada_Pembelajaran_Tematik_Terpadu_Di _Sekolah_Dasar

Pranowo, T. A., \& Prihastanti, A. (2020). Pengaruh Bimbingan Kelompok Melalui Media Audio Visual Terhadap Motivasi Belajar Siswa. Indonesian Journal of Learning Education and Counseling, 2(2), 217-223. https://doi.org/10.31960/ijolec.v2i2.338

Priyambodo, E., Wiyarsi, A., \& Sari, R. L. P. (2012). Pengaruh media pembelajaran interaktif berbasis web 
terhadap motivasi belajar mahasiswa. Jurnal Kependidikan Penelitian Inovasi Pembelajaran, 42(2), 99109. https://doi.org/10.21831/jk.v42i2.2236

Rerung, N., Sinon, I. L. ., \& Widyaningsih, S. W. (2017). Penerapan Model Pembelajaran Problem Based Learning (PBL) untuk Meningkatkan Hasil Belajar Peserta Didik SMA pada Materi Usaha dan Energi. Jurnal Ilmiah Pendidikan Fisika Al-Biruni, 6(1), 47-55. https://doi.org/10.24042/jpifalbiruni.v6i1.597

Romadhoni, I., Mahardika, I. K., \& Harijanto, A. (2017). Penerapan Model Pembelajaran Problem Based Learning (Pbl) Disertai Media Cd Interaktif Terhadap Hasil Belajar Dan Aktivitas Belajar Siswa Pada Pembelajaran Fisika Sma Di Kabupaten Bondowoso. Jurnal Pembelajaran Fisika Universitas Jember, 5(4), 329-336.

Sari, D. S., \& Sugiyarto, K. H. (2015). Pengembangan Multimedia Berbasis Masalah Untuk Meningkatkan Motivasi Belajar Dan Kemampuan Berpikir Kritis Siswa. Jurnal Inovasi Pendidikan IPA, 1(2), 153166. https://doi.org/10.21831/jipi.v1i2.7501

Sari, N. A., Akbar, S., \& Yuniastuti, Y. (2018). Penerapan Pembelajaran Tematik Terpadu di Sekolah Dasar. Jurnal Pendidikan: Teori, Penelitian, Dan Pengembangan, 3(12). https://doi.org/https://doi.org/10.17977/jptpp.v3i12.11796

Setyaningsih, S., Rusijono, R., \& Wahyudi, A. (2020). Pengaruh Penggunaan Media Pembelajaran Interaktif Berbasis Articulate Storyline Terhadap Motivasi Belajar dan Hasil Belajar Siswa Pada Materi Kerajaan Hindu Budha di Indonesia. Didaktis: Jurnal Pendidikan Dan Ilmu Pengetahuan, 20(2), 144-156. https://doi.org/10.30651/didaktis.v20i2.4772

Tembang, Y., Purwanty, R., \& Hermansyah, A. K. (2020). Implementasi model think pair share berbantuan media Kahoot It meningkatkan keaktifan berdisikusi mahasiswa. Premiere Educandum: Jurnal Pendidikan Dasar Dan Pembelajaran, 10(1), 22-33. https://doi.org/10.25273/pe.v10i1.5368

Tomas, \& Prasetyo, T. (2020). Pengaruh Penggunaan Model Problem Based Learning (Pbl) Terhadap Motivasi Belajar Matematika Pada Siswa Kelas 4 Sd. JPPGuseda| Jurnal Pendidikan \& Pengajaran Guru Sekolah Dasar, 3(1), 13-18. https://doi.org/10.33751/jppguseda.v3i1.1919

Wajdi, F. (2017). Implementasi Project Based Learning (PBL) Dan Penilaian Autentik Dalam Pembelajaran Drama Indonesia. Jurnal Pendidikan Bahasa Dan Sastra, 17(1), 81-97. https://doi.org/10.17509/bs_jpbsp.v17i1.6960

Wati, L. A. (2013). Pemanfaatan Media Video Pembelajaran Untuk Meningkatkan Hasil Belajar IPS Pada Siswa Kelas IV SDN Babatan I/456 Surabaya. Jurnal Penelitian Pendidikan Guru Sekolah Dasar, 1(1). https://jurnalmahasiswa.unesa.ac.id/index.php/jurnal-penelitian-pgsd/article/view/792

Yunita, D., \& Wijayanti, A. (2017). Pengaruh Media Video Pembelajaran Terhadap Hasil Belajar Ipa Ditinjau Dari Keaktifan Siswa. Sosiohumaniora: Jurnal Ilmiah Ilmu Sosial Dan Humaniora, 3(2), 153-160. https://doi.org/10.30738/sosio.v3i2.1614 